\title{
NYERE OPSLAGSVÆRKER OM RELIGION
}

\author{
Finn Stefánsson
}

Vi lever i encyklopædismens tidsalder, påstås det. I postmodernismens periode er det typiske den fragmenterede karakter, og hertil passer leksikongenren som fod i hose. I denne forsøger man at samle og sammenfatte viden inden for et fag, fx religion, eller al tilgængelig viden, i encyklopædiske værker. Men den form er måske selv et eksempel på, at det ikke længere lader sig gøre at sammenfatte og at fortolke verden entydigt.

I forbindelse med modtagelsen af Gads Bibel Leksikon i foråret 1998 blev der peget på et andet aspekt i udgivelserne: Forældelsestempoet skrues i vejret. Et helt nyt paradigme skal til. Povl Götke sammenfatter således i sin anmeldelse (Weekendavisen 13.-19. marts 1998): "Måske er det lige præcis den tiltagende flygtighed og fragmentering, der skaber behovet for en samling og fiksering. Encyklopædiske bestræbelser er måske en form for mentalhygiejnisk nødvendighed. En samling og fiksering af viden på trods og mod bedre vidende, så at sige." Jeg er nu ikke så sikker på, at viden forældes; men ny viden kommer til og dermed også nye fortolkningsvinkler på stoffet. Et markant eksempel er netop forskningen i GT og Israels historie.

Den encyklopædiske genre er på mode: Brøndums Forlag har udgivet en 'spøjs' Encyklopcedi, og Klaus Rifbjerg har udgivet en digtsamling, Leksikon, der bygger på de ord i Gyldendals 2-binds Leksikon, der tændte ham etc. Store udenlandske 'encyklopædiske' forfattere som Roland Barthes, Umberto Eco og Jorge Luis Borges læses intenst $i$ disse år. Hver nation med respekt for sig selv udgiver en nationalencyklopædi. Ideen er ikke blot oppustet nationalisme; at hvert land faktisk tyder tilværelsen temmelig forskelligt, kan man se ved at sammenligne nationalencyklopædierne i de tre nordiske lande, der jo ellers har så meget fælles, at de kaldes broderfolk. Disse nationalleksika er - med et lidt stort begreb - med til at skabe identitet: Hvad kan der på et givet tidspunkt på et givet sted siges om bl.a. tilværelsens store grundbegreber.

I denne "review-artikel" vil jeg kort opholde mig ved den danske leksikonsituation, herunder fortælle lidt om mit eget 'leksikografiske' arbejde i de sidste godt 20 år; men udgangspunktet for artiklen er en række engelsksprogede religionsopslagsværker fra de sidste årtier, især The Oxford Dictionary of World Religions, ed. John Bowker, 1997 (herefter Oxford) og J.R. Hinnells' (ed.) to værker fra Penguin: Penguin Dictionary of Religions, 1997 (herefter Penguin), og Who's Who of Religions, 1996 (herefter Who's Who). Men jeg inddrager også fire andre opslagsværker til sammenligning: The Perennial Dictionary of World Religions, ed. Keith Crim, 1989 (herefter Perennial); Macmillan Dictionary of Religion, ed. Michael Pye, 1994 (herefter Macmillan), The Wordsworth Dictionary of Beliefs \& Religions, ed. Rosemary Goring, 1995 (herefter 
Wordsworth) samt Geoffrey Parrinder: A Dictionary of Non-Christian Religions, 1971 (herefter Parrinder).

Ja, man kan blive helt svedt! Men det engelsksprogede marked rummer langt flere værker, end jeg her kan komme ind på - og jeg har ikke grundigt, dagligt kendskab til alle værker. Jeg kommer heller ikke ind på den efterhånden rige mulighed for at få viden via elektroniske medier, fx Encyclopedia Britannica's multimedia edition 99. Blandt bøger skal jeg blot nævne (og i øvrigt henvise til litteraturlisten): det meget roste The HarperCollins Dictionary of Religion, ed. Jonathan Z. Smith, San Francisco 1995; S.G.F. Brandon: Dictionary of Comparative Religion, New York 1970; Ninian Smart: The World's Religions, 1989 samt kæmpeværkerne Encyclopedia of Religion and Ethics, 1-13, ed. James Hastings, Edinburgh 1908-26 og The Encyclopedia of Religion, 1-12, ed. Mircea Eliade, New York 1986. Eliades værk udkommer på det sidste i en række separate bind med delområder, fx jødedommen. Endelig nævner jeg Curzon Press' serie Popular Dictionary, hvor der hidtil er kommet bind om buddhisme, hinduisme, islam, sikhisme og shinto; flere af bindene i denne serie virker dog ejendommelig antikverede og bygger da også på let reviderede ældre opslagsbøger.

En del af de nyere 'danske' opslagsbøger er faktisk oversatte og - eventuelt bearbejdede til den danske sammenhæng. Det gælder fx to myteleksika: Politikens bog om myter og Gyldendals Mytologisk leksikon (1993 og 1998) og en række symbolleksika: Politikens Symbolleksikon (1994), Gads Symbolleksikon (1991) og Fritiof Dahlbys Symboler og tegn i den kristne kunst (1979) og Symboler i kirkens billedsprog (1985) samt det ene af de 'okkulte' leksika: Sjolens leksikon (Gyldendal 1993/98). 'Rigtigt' danske er derimod Poul Ferslings Mystikkens verden (1978 og senere udg.); endvidere Jørgen Bæk Simonsens Politikens Islam leksikon, Lisbet \& Mogens Müllers Politikens Bibelleksikon (1980 og senere udg.), det nævnte Gads Bibel Leksikon (1998), andre værker om symboler (af Sven Tito Achen), Arild Hvidtfeldts Politikens Religionsleksikon (1991), Erik Thastums to bøger med leksikondele: Håndbog i religion (1990) og Håndbog i kristendom (1992) samt Religion/Livsanskuelse (1. udg. 1979; ny udg. og titel 1998: Gyldendals Religionsleksikon. Religion/Livsanskuelse). I skrivende stund (juli 98) ved jeg, at et nyt totalleksikon er på vej på Gad: Gaids Religionsleksikon, og der går rygter om lignende initiativer fra andre forlag. Også et større kirkehistorisk opslagsværk er på vej og måske et opslagsværk til nordisk mytologi og folketro.

Naturligvis er ikke alt lige godt i den store bunke, og en række af værkerne supplerer hinanden. Nævnes kan det fx, at der er meget stor forskel på kvaliteten af de oversatte symbolleksika: Gads er solidt, mens Politikens er rent opremsende, uden fokus. Hvidtfeldts religionsleksikon er - trods titlen - ikke et totalværk; det rummer 'kun' artikler om fremmede religioner og nyreligiøse bevægelser, dvs. mangler bl.a. kristendommen, nordisk religion og naturfolk. Til gengæld er det - ligesom Bæk Simonsens fremragende Islamleksikon - glimrende illustreret. Thastums bøger er til decideret skolebrug.

Min egen erfaring som leksikonskribent er på tre forskellige niveauer og strækker sig tilbage til ca. 1976. Dels har jeg løbende redigeret og skrevet til Religion/Livs- 
anskuelse; dels har jeg redigeret og skrevet samtlige artikler om religion til Gyldendals almindelige leksikonudgivelser fra 1979 (dvs. bl.a. supplementbindet til Gyldendals 10-binds leksikon, 2-binds-leksikon, Fakta), og frem til i dag (med den nye kompaktleksikonudgivelse, Memo, projekteret til udgivelse i 2000, er jeg for forste gang ikke 'alene' som redaktør og skribent; Gyldendal har her valgt en arbejdsform, som er en minimodel af Encyklopædiens); dels har jeg fra 1992 været først "superkonsulent" for religion på Den Store Danske Encyklopcedi, siden konsulent og skribent ved de områder af religion, jeg har særlig forstand på; betegnelsen "superkonsulent" kræver en bemærkning: det er forlagets egen (ironiske?) betegnelse for den eksterne person, man har bedt om at hjælpe redaktionen med at skitsere et fags områder, artiklers omfang etc., foreslå konsulenter og evt. også skribenter til et delområde.

De sidste to års intense arbejde med Gyldendals Religionsleksikon. Religion/Livsanskuelse har lært mig, at det er rigtigt, at faget udvikler sig med rivende hast. Jeg har skrevet omkring 700 nye artikler til værket og kunne have tænkt mig i hvert fald 200 flere, men der har været pladshensyn at skulle tage. Religion/Livsanskuelse er oprindelig skrevet af 25 eksperter, og i den nye udgave er disse suppleret med 5 nye. Værket har fra første færd - men endnu mere i nyeste udgave - bygget på en faglig profil med bredde og global vinkel som udgangspunkt og med åbninger til andre fag som filosofi, antropologi, idehistorie og kulturhistorie. Jeg bilder mig ind, at mine mange studierejser i fjerne kulturer har kunnet smitte af på det globale i værket: Det er lettere at bruge elefantprocessionen i Kandy, Sri Lanka, når man selv har overværet den, det er lettere at gøre rede for den symbolske struktur i Borobudur, når man har besteget det kæmpemæssige bygningsværk, eller for Damaskus', Kyotos og Naras religiøse topografi, når man selv har vandret i byerne. Men der er også en dansk vinkel på stoffet og en dansk faglig tradition, som gør dette værk anderledes end fx de engelsksprogede, der skal omtales senere. Det mest spændende ved den opslagsværksform er nok, når man får skrevet noget med et overraskende perspektiv i, en vinkel der åbner til fx det komparative, æstetiske, etiske eller eksistentielle; derudover skal artiklerne selvfølgelig gerne være præcise og læsbare.

Det præcise og læsbare er naturligvis alfa og omega $\mathrm{i}$ artikler til et almindeligt leksikon; her kan man ikke boltre sig i sammenligninger mellem religioner eller lade en artikel klinge ud i et personligt perspektiv. Fakta skal være fakta og Memo ligeså! Der er jo også radikale pladshensyn at tage. Gennemsnitslængden for en artikel er på ca. 8 linier, og kun ganske få artikler er på over 25 linier. Overordentlig mange gange må man, når man skriver i tusindvis af artikler gennem årene, naturligvis også nøjes med sekundær viden om et område inden for faget og så stole på sin fingerspidsfornemmelse for, at det er det rigtige at skrive. Men det er da en tilfredsstillelse at forsøge på at skrive kort, præcist og forståeligt og trods alt kunne vælge, prioritere og belyse selvstændigt til et værk, der har været/er en vigtig vidensbank for hundredtusinder af danskere.

Jeg kan derimod ikke mindes en mere omfattende skrive- og redigeringsproces end den, der finder sted over for hver linie i hver artikel i Encyklopcedien. Artiklerne skrives 
af deciderede eksperter, men bliver før tryk læst og kommenteret af en stribe konsulenter, granskere, etymologer, sproglige feinschmeckere etc. Det er i sandhed imponerende, bekosteligt og omstændeligt. Det er min erfaring, at det giver pote. En særlig force ved Encyklopcedien er de store essays om begreber som angst, fantasi, inspiration - og hele det tværfaglige projekt: Religionshistorikere, antropologer, geografer etc. kan bidrage til den enkelte artikel, måske en artikel på blot 12-15 linier. Der er rig - men ikke ubegrænset - mulighed for at anlægge personlige vinkler på stoffet. På mange måder er vinklen den samme som i Religion/Livsanskuelse, men dels files der mere, dels er det tværfaglige mange gange en styrke.

Man kunne godt drømme om et dansk religionsopslagsværk i 3 bind på ca. 1.500 sider; i et sådant ville min intention om det perspektiverende, sammenlignende og personlige kunne gå op i en højere - videnskabelig - enhed. Men det ville kræve vel 3 års fuldtidsarbejde af en redaktionsgruppe på vel 3-5 personer og 100-150 skribenter tilknyttet projektet.

De ca. 1.000 sider er derimod lige ved at være normalt for de engelsksprogede værker. Oxford er på 1.111 tætpakkede sider. Eneste illustration er en mediterende thailandsk buddhistmunk på et smukt skinnende flisegulv på bogens smudsomslag. Generelt må man sige om de engelsksprogede værker, at illustrationerne er ringe og gnidrede. Bedst blandt de omtalte værker er faktisk en konsekvent illustrering med tegninger i Parrinder. Hvor der bruges fotos, er papirkvaliteten ofte så ringe, at man knapt kan se, hvad fotografierne forestiller. Bøgerne er da også billigere end de danske i forhold til deres omfang. Men når man tænker på, hvordan ikke mindst Politikens Forlag mestrer illustrationskunsten, kan man godt forbløffes over den ringe vægt, man lægger på det i den engelsksprogede verdens opslagsværker (man har derimod overdådigt illustrerede værker til $\mathrm{fx}$ gennemgange af religioners mytologier; men her inddrager jeg kun deciderede opslagsværker som eksempelmateriale).

Oxford har John Bowker som chefredaktør, 8 konsulenter og 80 skribenter fra især engelske og amerikanske universiteter. Bowker indleder selv med et ca. ti siders essay om religion; så følger 8.200 artikler; værket afsluttes med et omfattende "Topic Index", hvor man kan slå op på hovedbegreber og i nogle tilfælde finde hundredvis af henvisninger til steder i bogen, hvor det begreb omtales, og med et dobbelt index over kinesiske ord opstillet efter henholdsvis Wade-Giles' og Pinyin Conversion Tablesystemerne.

Titlens "World Religions" skal forstås som verdensreligioner og ikke verdens religioner. 'Døde' religioner og naturfolks religioner er $\mathrm{fx}$ ikke med. Det giver af og til lidt ejendommelige valg: Der er fx ikke en artikel om maoriernes (eller polynesiernes) religion, fordi det ville være verdens religioner, men derimod om kristne kirker i New Zealand med maoriislæt, fordi kristendommen er en verdensreligion (det bliver derfor vanskeligt helt at fatte forholdene i maorikirker som Ratana og Ringatu; man savner unægtelig den lokale baggrund). 50 sider mere - om naturfolk - og det problem ville være undgået. 
Som eksempel på hvor fyldigt et område behandles, tager jeg 'Buddhism'. Selve hovedartiklen er kun på 2 sider, en rent historisk placering, som kan læses sammen med artiklen 'Buddha' af tilsvarende længde; men så følger - ofte lange - artikler om 'Buddhism in Britain, in China, in Japan, in Korea, in South-East Asia, in Tibet'; to sider om 'Buddhist schools' og 1 spalte om 'Buddhist Scriptures'; man finder også en spalte om den store thai-buddhist Buddhadasa (f. 1905), og den allernyeste udvikling $i$ lande som Thailand og Vietnam er glimrende behandlet. Stykket om 'Buddhism in Japan' er derimod helt historisk; vil man have blot en lille bid af den mangfoldige udvikling i de sidste 50 år, må man slå op under 'Japanese Religions' og 'New Religions in Japan', den sidste dog så kortfattet, at den næsten intet giver.

Kristendommen behandles på linie med de øvrige verdensreligioner, selv om der faktisk hos Oxfordforlaget findes et stort opslagsværk om kristendommen: The Oxford Dictionary of the Christian Church (1. udg. 1957, seneste 1997). Indien, Kina og Japan er fremragende dækket ind. Som man ofte ser i engelsksprogede værker, er behandlingen af sikhisme og zoroastrianisme/zarathustrisme næsten lige så fyldig som hvad, vi er vant til at opfatte som hovedreligionerne. Det giver sig af og til lidt barokke udslag, også fordi sikh- og zoroastrianismeskribenterne tilsyneladende har svært ved at fatte sig i korthed. Talrige artikler rummer ( $\mathrm{fx}$ 'festivals', 'funeral rites', 'marriage and divorce') afsnit om hver af verdensreligionerne; det kan virke lidt stereotypt, at man hver gang skal hele rækken igennem, men der er bestemt også kvaliteter ved den metode. Man bemærker, at der også er perspektivrige artikler af typen 'alchemy', 'alcohol', 'ancestors', at filosoffer (fx Hume) og psykologer (fx Maslow) ikke er glemt. De fyldige litteraturhenvisninger efter artiklerne rummer især en række helt nye værker (langt de fleste henvisninger er til værker fra de sidste 20 år). Bogen er et videnskabeligt værk af høj karat.

Af Hinnells' værker bygger Penguin på et leksikon fra 1984, men er i 1997-udgaven en del ændret; værket er på 760 tættrykte billigbogssider med 11 (!) illustrationer. Det er skrevet af 65 bidragydere fra 12 forskellige lande. Der er noget meget kompakt over bogen, men også meget praktisk. Efter forordet følger en 37 siders liste over bogens delområder og forfattere: her er $\mathrm{fx}$ en halv side med de ca. 40 begreber, der bruges inden for afrikanske religioner. Efter leksikondelen følger en bibliografi, der er på intet mindre end 100 sider, igen inddelt efter bogens delområder. Det er noget kompliceret at slå litteratur op ud fra den enkelte artikel, der bruger romertal og arabertal som henvisningssystem til bibliografien; men til gengæld er der virkelig gods i bibliografien, selv om den mest holder sig til engelsksprogede værker. Bogen afsluttes med et index, der også er på 100 sider.

Penguin omhandler alle religioner, også kristendommen, naturfolk og de antikke religioner, fx egyptisk religion. Man kan bemærke, at der er gjort meget ud af de nyeste bevægelser, fx hele 40 opslag om afro-caribiske religioner, tilsvarende om latinamerikansk religion og nye religioner $\mathrm{i}$ Vesten. Selv om nordisk religion skrives af en absolut kapacitet, H.A.E. Davidson, er området noget sparsomt belyst, fx er der ikke specialartikler om Frej, Freja, Frigg; kun i index kan man finde de steder, hvor de er 
omtalt i andre artikler. Værket lægger stor vægt på den geografiske placering; masser af 'paraply'-artikler har det enkelte land som udgangspunkt (fx kristendom i Korea, islam i Amerika), og som eksemplet islam i Amerika viser, tager man i høj grad de seneste tiårs migration med $\mathrm{i}$ behandlingen. På det punkt vil jeg karakterisere værket som det bedste, jeg har set.

Penguin rummer så godt som ikke helt korte artikler; definitionerne er snarere lagt ind $\mathrm{i}$ halvlange og lange artikler på fra $1 / 2$ spalte til 2 sider. Religiøse begreber og idehistoriske perioder får man fyldig, men noget kontant besked om; der er ikke den store perspektivering i artiklerne. En artikel som 'Enlightenment' tillader sig dog at perspektivere med ganske få linjer om Oplysningstidens betydning i dag, men efter en facts-spækket 2 siders behandling med særligt henblik på bibelkritikken, hvor det formelig fyger med navne og årstal.

Penguin bør ses i sammenhæng med Hinnells' Who's Who, der da også er udgivet $i$ helt tilsvarende udstyr. Værket er på 560 sider, skrevet af 68 bidragydere fra måske 20 forskellige lande. Igen er der denne supergrundige bibliografi, på 60 sider, inddelt efter bogens 26 delområder, 15 sider kort (som unægtelig snarere burde være placeret i Penguin), og synoptisk (dvs. efter delområderne, $\mathrm{fx}$ afrikanske religioner) og generelt index. Bredden er der igen: der er både antikke og nye opslag, og det er hele verden der belyses. Man leder ikke forgæves efter 'Olav the Holy' ,'Harald Bluetooth Gormsson', 'Buddhadasa', 'Black Elk' eller 'Desmond Tutu'. Det er svært at finde huller i det religiøse portrætgalleri; fx er de tre lederskikkelser i 'Soka Gakkai' med, Toda dog lagt ind i artiklen om 'Makiguchi'; i Penguin's artikel om 'Soka Gakkai' mangler derimod den nyeste udvikling i sekten, bl.a. omkring Ikeda Daisaku. De ledende okkultister, $\mathrm{fx}$ Blavatsky og Steiner, er naturligvis med, men også Carlos Castaneda, der min salighed får en hel spalte. Af og til kan man synes, der tages for meget med: Bach, Händel, Mozart og andre komponister har - mindre - portrætter, med henblik på de religiøsekirkelige dele af deres musik, men man får faktisk også små generelle biografier om dem. Ja, men burde så ikke også en række skønlitterære forfattere, fx Goethe, tages med? Af danskere er vist kun Kierkegaard og før omtalte Blåtand med. Man savner Saxo, Grønbech, Knud Rasmussen, Lehmann, Løgstrup - og får ad den vej sporet sig ind på, at der i det hele taget er for få forskere med; der lægges mere vægt på den religiøse personlighed. Omfanget er fra ca. 1/2 spalte til 2 sider ( $\mathrm{fx}$ 'Buddha', 'Moses', 'Muhammad'). Igen må man sige, at der skrives ganske håndfast og kompakt; man făr virkelig noget at vide, men savner lidt spændende vinkler. Ingen skal være i tvivl om, at jeg er begejstret for de to bind; de er på niveau med Bowkers værk.

Det samme gælder til en vis grad den 830 sider lange (med særdeles store sider) Perennial; værket er mig bekendt ikke optrykt efter 1989 og kan være vanskeligt at få fat på og er vel også delvist erstattet af samme forlags opslagsværk fra 1995, udgivet af J.Z. Smith. Perennial har én 'General Editor' og to 'Associate Editors' og 160 medarbejdere. Hovedparten er helt tydeligt amerikanske universitetsfolk; det ses også på udvælgelsen og prioriteringen: Der er fx lange afsnit om 'Native American Tribal Religion' og 'South American Tribal Religions'. Det ses, at man her forstår 'World 
Religions' som verdens religioner; naturfolk er med og fornemt behandlet; men stadig ikke de 'døde' religioner, fx heller ikke mayaernes religion, der knapt kan kaldes 'død'. Der er 'kun' 1600 artikler, dvs. en gennemsnitslængde på en halv side. De mange store artikler (fx 'Art and Architecture' på 20 s., 'Buddhism' på 25 s., 'Hinduism' på $20 \mathrm{~s}$., 'Christianity' på $15 \mathrm{~s}$., 'Islam' på $20 \mathrm{~s}$., 'Mysticism' på $5 \mathrm{~s}$.) har afhandlingens omfang og dybde. Som i Oxford er der ofte tværgående behandling, så man inden for et begreb har afsnit om fx forholdene inden for en række religioner. Svagheden ved værket er det lidt for tilfældige valg af begreber og længden af artikler om centrale begreber (som 'mana' og 'taboo', der begge spises af med få linier). Helt tilfældigt virker valget inden for de nyeste områder, fx nye religioner, og de særdeles fyldige bibliografier efter artiklerne rummer næsten ikke værker fra de sidste 30 år. Heldigt er det heller ikke, at artiklen 'Marriage and Divorce' kun omhandler forholdene inden for islam.

En decideret billigbog (kan fås via forlaget Futurum for ca. $30 \mathrm{kr}$.!) er Wordsworth på 590 unægtelig ikke glittede sider. Bogen har udgangspunkt i en gammel sag, The Book of Ceremonial Magic (1911) og er i den nye udgave lidt gammeldags $i$ hele tilgangen til faget. Den er skrevet af 15 britiske universitetsfolk (mange skotske) og udstyret med få, men ganske gode stregtegninger. Den indledes med 32 sider "Entries by Subject", hvor man kan finde de begreber der behandles i hoveddelen opstillet alfabetisk inden for fx 'Buddhism' (ca. 200 begreber) og 'Christianity' (ca. 500 begreber); og afsluttes med festkalender og statistik for hver religion fra hvert land. Hoveddelens ca. 3.000 artikler er hovedsagelig korte eller halvkorte, dvs. fra 10 linier til 1 spalte; men der er også eksempler på spændende tværgående behandling (fx 'marriage/divorce', der udfoldes kristent, islamisk og jødisk, men ikke fx indisk eller kinesisk). Alt $\mathrm{i}$ alt savner man dog større artikler om fx buddhisme (hovedartiklen er kun på 1 spalte), islam ( 1 spalte); 'små' og 'store' begreber får næsten altid behandling af samme omfang. Værket har også en del filosofisk og idéhistorisk stof med og har en behageligt bred vinkel på religionsfaget.

Macmillan har engelsk hovedredaktør fra Lancaster og 7 engelske hovedkonsulenter; men i øvrigt er de 43 medarbejdere universitetsfolk fra en række europæiske lande og USA, Canada og Japan. Værket er på 319 sider og rummer 5.500 artikler. Der afsluttes med en 20 siders alfabetisk ordnet bibliografi; ved de enkelte artikler er der så henvisning til forfatter og år. Artiklerne er korte, men særdeles præcise; man undrer sig over fordelingen af linietal, $\mathrm{fx}$ har islam og hinduisme begge under 10 linier! Bogens force er de mange begreber også fra helt fjerne kulturer som Oceanien og Indonesien, som man sjældent tilgodeser. Men Macmillan mangler spændende vinkler; der er ingen tværgående artikler, og der mangler også en del af de 'store' begreber ( $\mathrm{fx}$ kan man ikke finde en artikel om 'marriage/divorce').

Parrinder er én mands værk. Geoffrey Parrinder er født 1910 og var indtil 1977, Professor of the Comparative Study of Religions ved University of London. Bogen er på 320 sider og slutter med en ganske kort litteraturliste, hvor det først nævnte værk er en Encyclopedia of the World's Religions, edited by G. Parrinder. Som næunt har bogen en del år på bagen (fra 1971); dens mange stregtegninger går an, men de noget 
færre fotografier er ringe gengivet. Som det fremgår af titlen er den uden kristendommen; den rummer nok 5000 artikler, de fleste ganske korte og ganske kontant oplysende. Den har 'døde' religioner med, fx også nordisk religion (et tilfældigt opslag rummer på en side 'Gungnir', 'Gylfaginning' og 'Gymir' - det viser da noget om værkets detaljeringsgrad). Koncentrationen er omkring det mytologiske navnestof; svagheden er dens kortfattethed og mangel på fænomenologisk, komparativ eller perspektiverende dimension. Den er som Macmillan egnet til det hurtige opslag, men ikke til fordybelse.

Til slut nogle betragtninger over forholdet mellem objektivitet og subjektivitet $\mathrm{i}$ sådanne fremstillinger. Ikke alt man møder i religioner og livsanskuelser er jo af (lige) høj kvalitet; det er vist Johs. Aagaard, der engang har udtalt, at $90 \%$ af alle religioner/al religiøsitet er noget makværk. Det er måske nok i overkanten! Det forekommer let efter så mange års beskæftigelse med området - at lave en slags kvalitetsprioritering; der er således stor forskel på 'kernen' i religionerne og de religiøse bevægelser, og de misbrug der har fundet sted og finder sted i religionernes praksis. Kvalitetskernen er så begreber som næstekærlighed, medliden/medfølelse, radikalt engagement, humant eller humanistisk sindelag, solidaritet, økologisk balance, fællesskab, lighed, frihed og befrielse; men også filosofisk dybde, de hellige teksters, bygningers og ritualers æstetiske skønhed. Højsangens og Koranens poesi ligger milevidt over reklame- eller traktatagtige tekster fra religionernes overdrev. Misbrug er fx hellig krig, mission med våben i hånd, hierarkiske strukturer, fanatisme og fundamentalisme, uselvstændiggørelse, manipulation og massesuggestion ('hjernevask'), fastlåste, doktrinære systemer, vildt asketiske og apokalyptiske aspekter, massemediebombardement af supermarkedsagtige frelsestilbud, ødelæggelse eller forkrampning af væsentlige sider af tilværelsen her og nu. Hvordan er fx ikke kernen i Jesus-skikkelsens budskab i forhold til mange af de 'kirkelige' lag i historiens løb? Hvordan er fx ikke Gandhis fortolkning af hinduismen i forhold til en hindufanatikers? Eller Buddhas tilværelsestolkning i forhold til den magisk-ritualistiske praksis med brug af amuletter etc., der er så udbredt i den buddhistiske verden?

Det kunne såmænd nok også lade sig gøre at opstille en slags kvalitetshierarki ikke blot inden for den enkelte religion, men også religionerne imellem - det skal jeg dog undlade her. En ting skal man dog vare sig imod: det er ingen grundregel, at en ny religion er ringere end en gammel; religioner opstår jo som knopskydninger, der ofte er mere og mere eksalterede, men også kan rumme fine nye blomster. Til gengæld må det også slås fast, at religionerne ikke med nødvendighed udvikler sig i betydningen at nå højere og højere stadier.

I en objektiv fremstillingsform, som leksikongenren jo er, kan man naturligvis ikke tillade sig rene nedsablinger af religioner eller dele af det religiøse liv; men i et tonefald vil begejstring eller mistro/kritik alligevel ofte vise sig, i de mange "ifølge traditionen", "medlemmerne mener", "en række forskere har undersøgt". 'Rene', positivistiske meninger findes jo ikke; der skal jo altid vurderes på en eller anden måde. Positivisme og objektivisme kan ende med at blive rædselsfuldt kedelig - og måske også 'falsk' . 
Ejendommeligt er det, at med det nye GT-paradigme er det netop i GT-stoffet man måske må indføre flest "ifølge traditionen", fordi GT har vist sig ikke just at være noget 'historieværk'. Men her skyldes "ifølge traditionen" så netop en dybtgående forskning i et område. GT-teksternes 'fiktionalitet' trækker ikke fra: De er jo netop både litteratur og livsanskuelse på højeste niveau.

\section{Litteratur}

\section{Engelsksproget}

BOWKER, JOHN, ed.

1997 The Oxford Dictionary of World Religions, Oxford.

BRANDON, S.G.F.

1970 A Dictionary of Comparative Religion, New York.

CARR, B. \& I. MAHALINGAM, eds.

1997 Companion Encyclopedia of Asian Philosophy, London \& New York.

CRIM, KEITH, ed.

1989 The Perennial Dictionary of World Religions, San Francisco.

ELIADE, M., ed.

1986 The Encyclopedia of Religion, 1-12, New York.

GORING, ROSEMARY, ed.

1995 The Wordsworth Dictionary of Beliefs \& Religions, Hertfordshire.

HASTINGS, J., ed.

1908-26 Encyclopedia of Religion and Ethics, 1-13, Edinburgh.

HINNELS, JOHN R.

1996 Who's Who of Religions, London.

1997 The Penguin Dictionary of Religions, London.

1997 A New Handbook of Living Religions, London.

LIVINGSTONE, E.A., ed.

1997 The Oxford Dictionary of the Christian Church, Oxford.

PARRINDER, G., ed.

1965 Encyclopedia of the World's Religions, Hamlyn.

PARRINDER, G.

1971 A Dictionary of Non-Christian Religions, London.

PYE, MiCHAEL, ed.

1994 Macmillan Dictionary of Religion, London.

SMART, NINIAN

1989 The World's Religions, Cambridge.

SMITH, J. Z., ed.

1995 The HarperCollins Dictionary of Religion, San Francisco.

ZAEHNER, R.D., ed.

1988 Encyclopedia of Living Faiths, London.

I serien A Popular Dictionary of ... er udkommet Buddhism (1994, C. Humphreys); Hinduism (1994, K. Werner); Islam (1994, I.R. Netton); Shinto (1996, B. Bocking); Sikhism (1994, W. Owen Cole \& P. Singh Sambhi). 
2. Dansksproget - original eller oversat

ACHEN, SVEN TITO

1986 Symboler - hvad er det?, København.

1985 Symboler omkring os, København.

BELLINGER, G. J.

1993 Mytologisk leksikon, København.

BIEDERMANN, HANS

1991 Gads symbolleksikon, København.

COOPER, J. C.

1994 Politikens Symbolleksikon, København.

DAHLBY, F.

1979 Symboler og tegn i den kristne kunst, København.

1985 Symboler $i$ kirkens billedsprog, København.

FERSLING, POUL

1978 Mystikkens verden, København.

FIBIGER, M.Q. \& G. SMITH, eds.

1999 Gads Religionsleksikon, København.

HALLBÄCK, G., H. J. LUNDAGER JENSEN \& B. WIBERG, eds.

1998 Gads Bibel Leksikon, København.

HVIDTFELDT, ARILD

1991 Politikens Religionsleksikon, København.

LUND, JøRN, ed.

1994ff Den Store Danske Encyklopadi, København.

MÜLLER, L. \& M.

1980 Politikens Bibelleksikon, København.

SIMONSEN, JøRGEN BÆK

1994 Politikens Islamleksikon, København.

STEFÁnsson, Finn \& Asger SøREnsEn, eds.

1998 Gyldendals Religionsleksikon. Religion/Livsanskuelse, København.

THASTUM, ERIK

1990 Håndbog $i$ religion, Herning.

1992 Håndbog $i$ kristendom, Herning.

WATSON, D.

1993 Sjælens Leksikon, København.

Finn Stefánsson

Lektor, cand. mag.

Peblingevej 58

4000 Roskilde 